\title{
South Africa's geothermal energy hotspots inferred \\ from subsurface temperature and geology
}

AUTHORS:

Taufeeq Dhansay ${ }^{1,2}$

Chiedza Musekiwa ${ }^{1}$

Thakane Ntholi ${ }^{1}$

Luc Chevallier $^{1}$

Doug Cole ${ }^{1}$

Maarten J. de Wit ${ }^{2}$

\section{AFFILIATIONS:}

${ }^{1}$ Council for Geoscience, Bellville, South Africa

${ }^{2}$ Africa Earth Observatory Network - Earth Science Stewardship Research Institute, Nelson Mandela University, Port Elizabeth, South Africa

\section{CORRESPONDENCE TO:}

Taufeeq Dhansay

\section{EMAIL:}

taufeeq.dhansay@gmail.com

\section{DATES:}

Received: 24 Mar. 2017

Revised: 22 May 2017

Accepted: 07 July 2017

\section{KEYWORDS:}

geothermometry; tectonics; renewable energy policy

\section{HOW TO CITE:}

Dhansay T, Musekiwa C, Ntholi T, Chevallier L, Cole D, De Wit MJ. South Africa's geothermal energy hotspots inferred from subsurface temperature and geology. S Afr J Sci. 2017;113(11/12), Art. \#2017-0092, 7 pages. http://dx.doi.org/10.17159/ sajs.2017/20170092

\section{ARTICLE INCLUDES:}

$\checkmark$ Supplementary material

$\times$ Data set

FUNDING:

None
South Africa intends to mitigate its carbon emissions by developing renewable energy from solar, wind and hydro, and investigating alternative energy sources such as natural gas and nuclear. Low-enthalpy geothermal energy is becoming increasingly popular around the world, largely as a result of technological advances that have enabled energy to be harnessed from relatively low temperature sources. However, geothermal energy does not form part of South Africa's future renewable energy scenario. This omission may be related to insufficient regional analysis of potentially viable geothermal zones across the country. We considered existing subsurface temperature and heat flow measurements and performed solutebased hydrochemical geothermometry to determine potentially anomalous geothermal gradients that could signify underlying low-enthalpy geothermal energy resources. We correlated these findings against hydro/geological and tectonic controls to find prospective target regions for investigating geothermal energy development. Our results show a significant link between tectonic features, including those oncraton, and the development of geothermal potential regions. In addition, potential regions in South Africa share similarities with other locations that have successfully harnessed low-enthalpy geothermal energy. South Africa may therefore have a realistic chance of developing geothermal energy, but will still need additional research and development, including new temperature measurements, and structural, hydrogeological and economic investigations.

\section{Significance:}

- The regional low-enthalpy geothermal energy potential of South Africa should be further researched for consideration of low-enthalpy geothermal energy as a renewable energy option.

\section{Introduction}

South Africa is the leading carbon emitter in Africa and has one of the highest rates of emissions of nations in the world. ${ }^{1}$ This status can be linked to South Africa's vast coal resources, which are an important contributor to the local mining sector and also account for more than $80 \%$ of South Africa's energy generation. ${ }^{1}$ South Africa intends to reduce its carbon emissions by producing about $40 \%$ of the country's total energy through renewable sources by $2030 .{ }^{1}$ This goal will be achieved mostly through solar-, wind- and hydro-generated forms of energy and largely accelerated by a Renewable Energy Independent Power Producer Procurement Programme, which has attracted considerable private-sector investment. ${ }^{1}$ Renewable energy alone will not meet South Africa's growing energy demands and therefore the country will also consider additional large-scale coal-fired energy, nuclear energy and energy produced from shale gas. ${ }^{1}$

Low-enthalpy geothermal energy is becoming increasingly popular around the world. ${ }^{2}$ This popularity is largely because it requires geothermal gradients as low as ca $40^{\circ} \mathrm{C} / \mathrm{km}$, which may be found in many global settings. South Africa does not have any active or recent volcanism and is situated far from any active continental and/or oceanic plate boundaries, but does have anomalously high heat flow regions that could meet the requirements for low-enthalpy geothermal energy development. ${ }^{3-5}$

In this study, we aimed to elaborate on potentially viable geothermal regions of South Africa. To do this, we considered existing heat flow, heat productivity, downhole temperature and hot spring data to conduct estimates of the geothermal gradient across South Africa. We calculated the geothermal gradient using thermodynamic principles for historical heat flow and heat productivity data and from solute-based geothermometry on hot spring hydrochemical data. We also correlated these results with high heat producing plutonic and volcano-sedimentary rocks, and established underlying tectonic influences using regional seismicity. We used these results to present a geothermal potential map of South Africa and we made recommendations toward including low-enthalpy geothermal energy in South Africa's future renewable energy mix scenario.

\section{Low-enthalpy geothermal energy}

Geothermal resources can be broadly classified into convective and conductive systems. These systems describe regions of the upper crust that exhibit anomalously high heat flow, and either have naturally occurring and/or circulating groundwater (i.e. convective), or are typically dry (i.e. conductive). Low-enthalpy geothermal resources represent systems in which groundwater circulating from a reservoir would not reach the surface with a temperature above ca $100^{\circ} \mathrm{C}$. High-enthalpy geothermal resources, on the other hand, are generally limited to global locations with active plate tectonics and consequentially active/recent volcanism, and where groundwater is heated to near and above supercritical levels. Low-enthalpy resources are usually associated with ancient tectonic activity and are often defined by plutonic rocks with high concentrations of heat-producing radiogenic elements (e.g. uranium and potassium) which are overlain by a thick and insulating volcano/sedimentary sequence. These conditions are commonly found in most parts of the world and may account for the increase in global low-enthalpy geothermal exploration (for more details refer to Huenges and Ledru²). 
Harvesting heat from a low-enthalpy geothermal resource commonly uses a binary mechanism with two independent and separated working fluids. In general, a geothermal fluid is circulated through a porous fractured reservoir in a targeted high heat producing plutonic assembly. Here simultaneous sequestration is also possible, for example through the incorporation of carbon dioxide in the geothermal fluid. Once the geothermal fluid is adequately heated, it is brought to the surface where it enters a generation plant. Within the generation plant, the heated geothermal fluid enters a heat-exchange mechanism under pressure and interacts with a second organic fluid that has a much lower boiling point. Conductive heat transfer causes the secondary fluid to flash to steam, which is then used to produce energy. Thereafter, the organic condensate is returned to the heat exchange system while the cooled geothermal fluid is cycled back into the fractured reservoir (Figure 1).

A comparative example of low-enthalpy geothermal energy development that may be considered here is within the Upper Rhine Graben (URG) along the border between Germany and France. The URG highlights extension along the Alpine foreland and in the Landau geothermal region (southwest Germany); it consists of fractured Palaeozoic basement granite with uranium content of up to ca $10 \mathrm{PPM}^{6}$, overlain by ca $1.5-\mathrm{km}$ thick Cenozoic, Mesozoic and Permian sedimentary rock sequences ${ }^{7}$. Rifting makes the URG seismically active ${ }^{8}$, with significant crustal thinning that enables uplift linked to mantle upwelling ${ }^{9}$. The average geothermal gradient throughout the URG is ca $35-45^{\circ} \mathrm{C} / \mathrm{km}$ with high heat flow evident from numerous hot springs. Hydrogeological properties throughout the URG are highly complicated ${ }^{10}$; however, the average groundwater yield rate as measured around geothermal sites and at a depth of ca $2 \mathrm{~km}$ is approximately $0.1 \mathrm{~L} / \mathrm{s} .{ }^{11} \mathrm{An}$ average $5 \mathrm{MW}$ low-enthalpy geothermal plant in the URG produces from reservoir temperatures of about $130{ }^{\circ} \mathrm{C}$ at an average depth of $3.5-4.5 \mathrm{~km}$ and production flow rates of $40-130 \mathrm{~L} / \mathrm{s} .{ }^{11}$ Heated water is typically used to run an Organic Rankine Cycle generation system with excess hot water diverted to provide household heating. There is approximately $30 \mathrm{MW}$ of installed low-enthalpy geothermal capacity within the URG with exploration and development continuing to increase. ${ }^{11}$

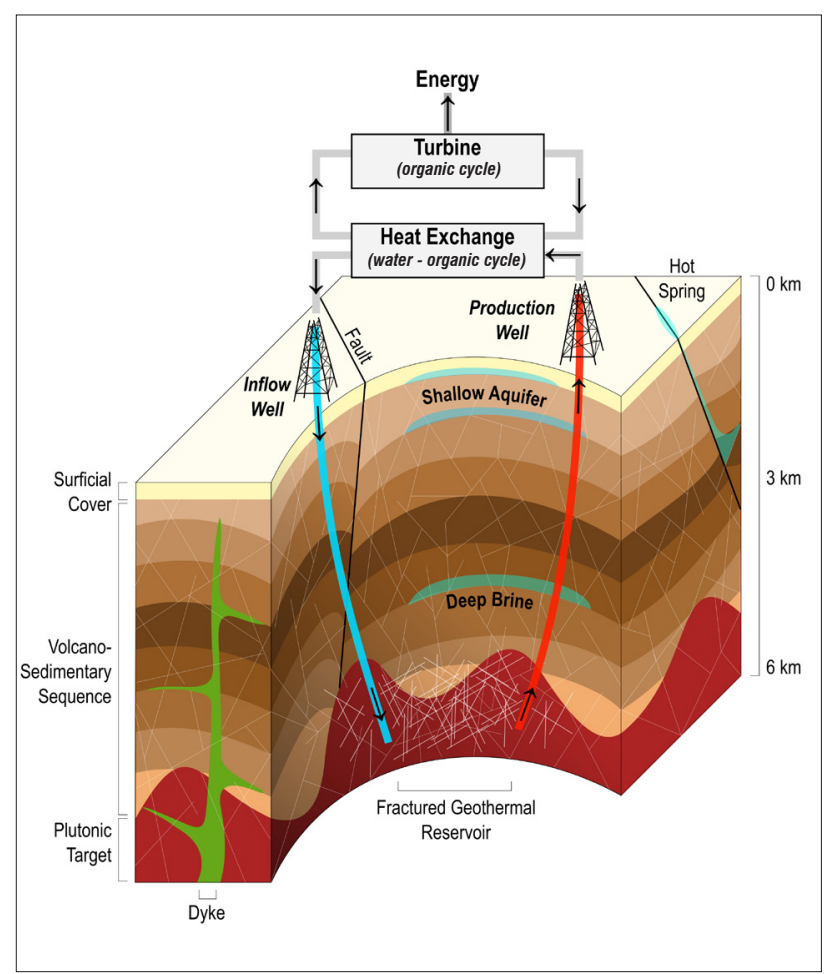

Source: Modified after Dhansay et al.3; refer to Huenges and Ledru² for more details.

Figure 1: Schematic illustration of a binary fluid enhanced geothermal system related to surrounding fracture-controlled geological features.

\section{Geological controls on heat flow in South Africa}

South Africa is partially underlain by the Kaapvaal Craton and its thick subcontinental lithospheric mantle keel that reaches depths of up to ca $250 \mathrm{~km}$ and has an average crustal thickness of $40-50 \mathrm{~km}^{12}$ (Figure 2). The Kaapvaal Craton comprises several smaller fragments of ancient crust that amalgamated and stabilised during the early Archean. Regions where amalgamation occurred appear as deep crustal discontinuities that may be likened to more recent plate tectonic boundaries. ${ }^{13}$ In general, the Kaapvaal Craton has a relatively low heat flow ${ }^{14-16}$, which has largely discouraged extensive geothermal investigation. However, subsurface temperature data suggest that there is at least some evidence for lowenthalpy geothermal energy potential on the Kaapvaal $\mathrm{Craton}^{4}$, and especially on the surrounding palaeo-orogenic belts ${ }^{3}$. These orogenic belts demarcate regions where continental collision had occurred. Regions showing apparent low-enthalpy geothermal energy potential, especially orogenic belts, share several characteristic geological and tectonic similarities. Most notably, orogenic belts display significantly higher heat flow signatures. ${ }^{3}$ This characteristic is especially illustrated by a ca $60 \mathrm{~mW} / \mathrm{m}^{2}$ heat flow increase across the boundary of the Kaapvaal Craton and the Namaqua-Natal Belt ${ }^{17,18}$, and similarly across the Limpopo Belt3.

Each orogenic belt is associated with tectonic evolutionary processes related to different supercontinent cycles; for example, the Limpopo Belt formed during the amalgamation of the Kalahari Craton ${ }^{13}$; the NamaquaNatal and Gariep Belts formed during the formation of Rodinia'9; and the Cape Fold Belt formed during the formation of Gondwana ${ }^{20}$. During these events convergent-related subduction resulted in the emplacement of partial melt-derived plutonic rocks, many of which are rich in heatproducing elements that release heat during the decay of radiogenic elements (Figure 2). For example, the Cape Granite Suite (Cape Fold Belt) has uranium concentrations of up to ca $34 \mathrm{PPM}^{21}$; the NamaquaNatal Belt has uranium concentrations of ca 10-54 PPM ${ }^{22,23}$; even older Archean granite-gneisses around Mombela (Nelspruit) ${ }^{24}$ and Johannesburg ${ }^{25}$ exhibit uranium concentrations of up to ca 20-28 PPM. In addition, Palaeoproterozoic tectonic activity along the ThabazimbiMurchison Lineament ${ }^{26}$ may have assisted in the emplacement of the Bushveld Complex, which includes felsic rocks that exhibit uranium concentrations of up to $30 \mathrm{PPM}^{27}$

Post-convergent extensive forces resulted in the formation of volcanosedimentary basins that overlie and insulate radiogenic plutonic rocks, and often exhibit their own elevated heat-producing signatures, particularly related to elevated and economically significant uranium concentrations, e.g. the Karoo Basin (largely overlying the Cape Fold Belt and the Namaqua-Natal Belt) 28 ; the Soutpansberg (overlying the Limpopo Belt) and Springbok Flats (overlying the Bushveld) ${ }^{28}$. Significantly elevated radiogenic signatures are also evident within the on-craton Archean Witwatersrand and Pongola Basin strata ${ }^{29}$; and especially from the Palaeoproterozoic Transvaal rocks. Here, partial melt derived products associated with the emplacement of the Bushveld Complex sometimes highlight anomalous uranium concentrations of up to 250 PPM. ${ }^{27}$

Higher heat flow signatures are further corroborated by numerous hot springs concentrated along orogenic belts and below the Karoo escarpment (Figure 2). Heating and circulation of groundwater is enabled by complex brittle fracture networks that were formed and reactivated during various plate tectonic events, e.g. hot springs located in the Limpopo Belt use a fracture network that was largely created during the Palaeoproterozoic and which underwent reactivation several times, including during more recent Mesozoic uplift. ${ }^{30}$

Another important link between the orogenic zones is an elevated number of natural seismic events ${ }^{31}$ which highlight stress release-reactivation along deep-seated brittle structures (Figure 2). For example, seismicity in the Karoo may be correlated with structures in the underlying NamaquaNatal basement32; and anomalous radon release within the Cape Fold Belt ${ }^{33}$, in addition to the occurrence of historically significant seismic events ${ }^{34}$, highlight the influence of stress release along deep structures. 


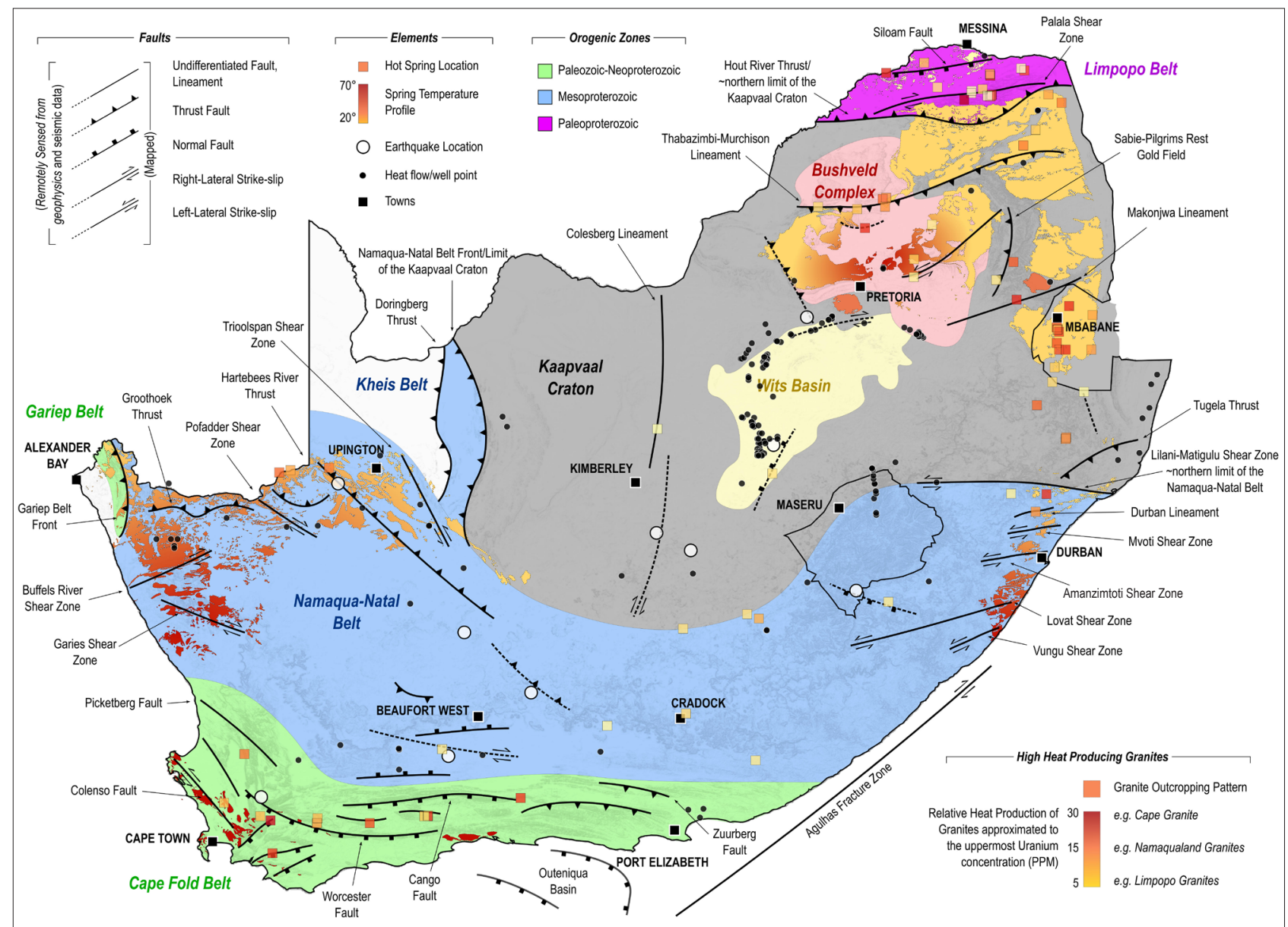

Sources: Tectonic information largely derived from 19, 26, 35-38

Figure 2: Overview of the major tectonic structures and zones across South Africa with the locations of significant earthquake focal mechanisms and inferred structures related to these events. Locations of the various data sources used within this study (e.g. hot springs and temperature measurement points) and high heat producing plutonic rocks are also highlighted. Note that the Namaqua-Natal Belt probably continues beneath the Cape Fold Belt as far as the offshore Agulhas Fracture Zone. ${ }^{12}$

\section{Geothermal gradient calculations}

In this study, we considered available data (Figure 2; also refer to supplementary material), including heat flow, heat productivity, downhole temperature measurements and solute-based equilibria geothermometry to highlight prospective zones for investigating low-enthalpy geothermal energy development. We normalised across the various data sources by calculating the theoretical geothermal gradient and using inverse distance weighting to interpolate these results across South Africa. For hot springs with only surface temperature information, we estimated circulation depths of ca 2-5 km, which we inferred from shallow geophysical investigations ${ }^{39,40}$, surrounding heat flow measurements and from deep borehole temperature data ${ }^{41}$. We also identified important tectonic structures and estimated the (most recent) underlying faulting dynamics based on earthquake focal mechanisms.

We calculated the geothermal gradient from heat flow and heat productivity data using principles of thermodynamics, where $Q$ represents the heat flow $\left(\mathrm{mW} / \mathrm{m}^{2}\right)$ and $\mathrm{C}$ represents the lithological thermal conductivity $\left(\mathrm{mW} / \mathrm{m} /{ }^{\circ} \mathrm{C}\right)$. Where no thermal conductivity measurements were available, we made estimations based on experimental thermal conductivity calculations ${ }^{42}$ and the known geological profiles. These factors are related by Fourier's Law:

$\frac{d T}{d Z}=\frac{Q}{C}$

Equation 1
We also calculated the geothermal gradient by applying solute-based equilibria geothermometry on available hot spring hydrochemical data and relate these results against the inferred hot spring circulation depths. Solute-based geothermometry estimates hot spring reservoir temperatures using the presence of equilibrated mineral cations, particularly silica, sodium and potassium. ${ }^{43}$ Importantly, unknown fluidrock interactions and/or sporadic infiltration/flow rates insinuate that hot spring reservoirs are not likely to be in a state of equilibrium and therefore this technique may not provide exact reservoir temperatures. Nevertheless, this method is still useful to establish a general estimate of hot spring reservoir temperatures. ${ }^{43}$ We used geothermometry limited to a maximum allowable temperature of $250^{\circ} \mathrm{C}$, including the silica-cation geothermometer:

$T=\left(\frac{1309}{5.19-\log S i}\right)-273.15$

Equation 2

where $\mathrm{T}$ is the reservoir temperature and $\mathrm{Si}$ is the concentration of dissolved silica in the water. We also used the Na-K geothermometer for springs with insignificant silica content and/or if silica content was not measured, where $\mathrm{Na}$ and $\mathrm{K}$ represent the concentration of dissolved sodium and potassium, respectively:

$T=\left(\frac{1217}{\log \left(\frac{\mathrm{Na}}{K}\right)+1.483}\right)$

Equation 3 


\section{Anomalous heat flow regions in South Africa}

The results of the geothermal gradient calculations are summarised in Figure 3. In general, the highest calculated geothermal gradients are closely related to naturally occurring seismic events and are situated within orogenic belts surrounding the Kaapvaal Craton. In addition, these orogenic zones account for the largest number of hot springs in South Africa. Anomalous geothermal gradients and hot springs are also found on the Kaapvaal Craton and are notably related to mapped cratonic discontinuities (e.g. the Colesberg and Thabazimbi-Murchison Lineaments). There is also a strong correlation between high geothermal gradients and the outcrop pattern of highly radiogenic plutonic rocks, particularly where these are overlain by volcano-sedimentary sequences (Figure 4).

\section{Discussion}

In general, orogenic belts surrounding the Kaapvaal Craton exhibit the highest heat flow signatures in South Africa, which may be linked to underlying geological, tectonic and crustal compositional controls, particularly related to the production of radiogenic material. These orogenic belts experience varying phases of convergent and extensive tectonics that often result in: the emplacement of high heat producing plutonic rocks ${ }^{21-23}$; the development of sedimentary basins, which were infilled by mostly siliciclastic sediments interspersed with often highly radiogenic volcanic extrusive material28; and finally the creation of complex brittle structural networks that enable thermal convective dispersion through natural groundwater flow ${ }^{50}$ and seismic-inducing stress release ${ }^{32}$.

Our results also highlight that high heat flow is not only restricted to off-craton regions. Zones near deep cratonic discontinuities also exhibit elevated geothermal gradients, which is especially noticeable along the Colesberg, Thabazimbi-Murchison and Makonjwa Lineaments. These zones highlight more ancient tectonic activity associated with the amalgamation and stabilisation of the Kaapvaal Craton $^{13}$ - processes that have apparently also imparted elevated heat flow signatures. These on-craton regions also have high heat producing plutonic rocks (e.g. Archean granite-gneisses around Mombela and Johannesburg; and Palaeoproterozoic Bushveld felsic rocks) and overlying volcanosedimentary basin sequences that exhibit their own high heat producing signatures (e.g. the Witwatersrand, Pongola, Transvaal and Springbok Flats). Anomalous heat flow and underpinning tectonic influences are also evident with the occurrence of hot springs and higher number of natural on-craton seismic events around these structures (Figure 4d). In general, seismicity related to these deep cratonic discontinuities highlight reactivation associated with a more recent northeast to southwest oriented extension ${ }^{31}$, which is in agreement with the present-day stress state seen in much of South Africa ${ }^{32}$.

Using the results of this study, together with high-yielding, shallow groundwater aquifers as a proxy for deeper hydrogeological conditions, and considering factors of successful development in Germany, we may highlight the most promising regions for investigating low-enthalpy geothermal energy development in South Africa (Figure 4). In no particular order, these areas especially include, but are not necessarily restricted to: (1) regions of the Cape Mountains, especially the Syntaxial region; (2) the southern Karoo; (3) the boundary of the Namaqua-Natal Belt and Kaapvaal Craton north of Durban; (4) the Bushveld Basin near the Thabazimbi-Murchison Lineament, north of Johannesburg; (5) the Limpopo Belt.

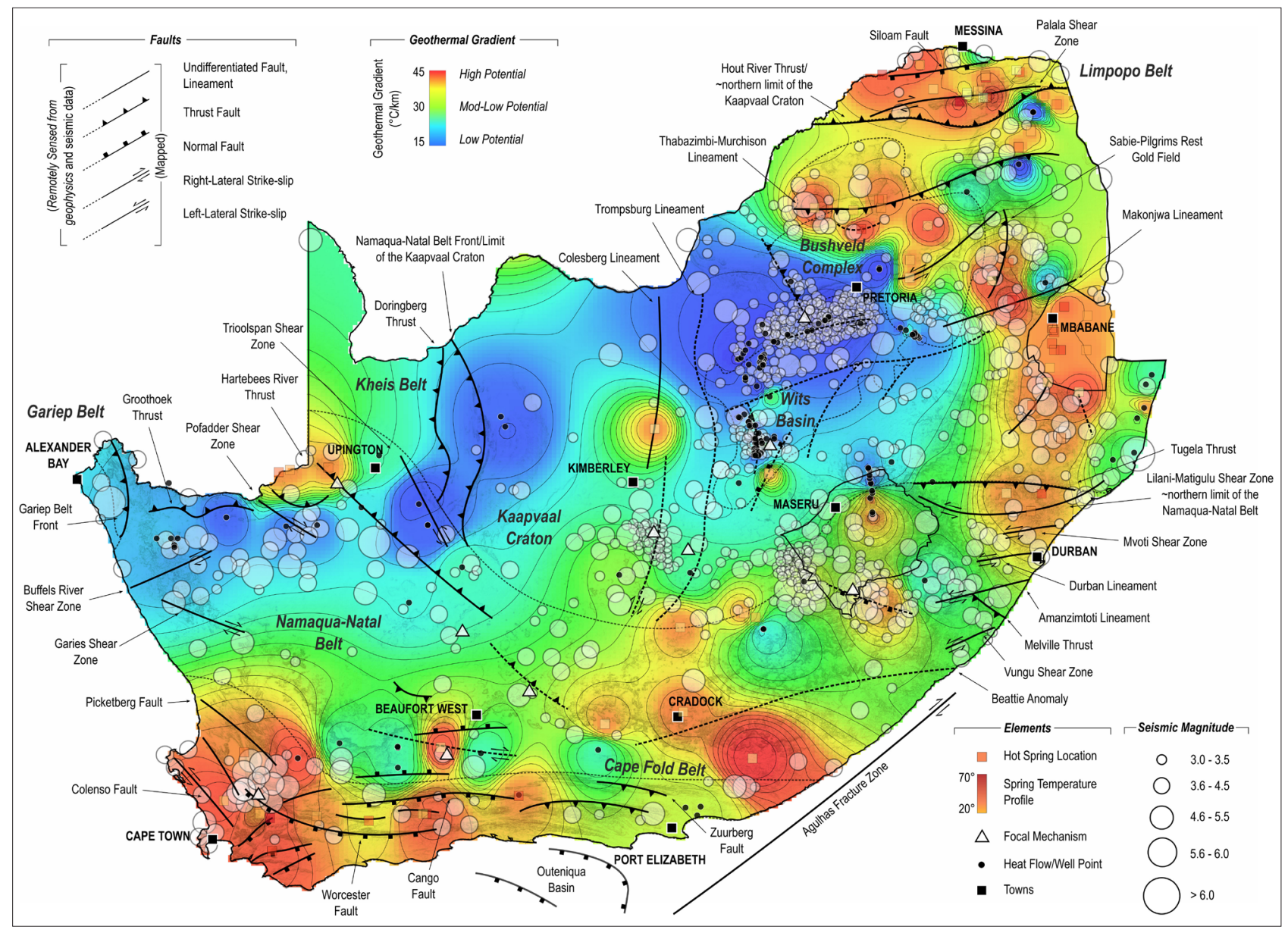

Sources: Temperature data derived from 5, 14-18, 44-59 and references therein.

Figure 3: Graphical overview of the calculated geothermal gradients across South Africa. Map includes major tectonic contacts and structures, seismic activity and earthquake focal mechanisms and hot spring locations. 


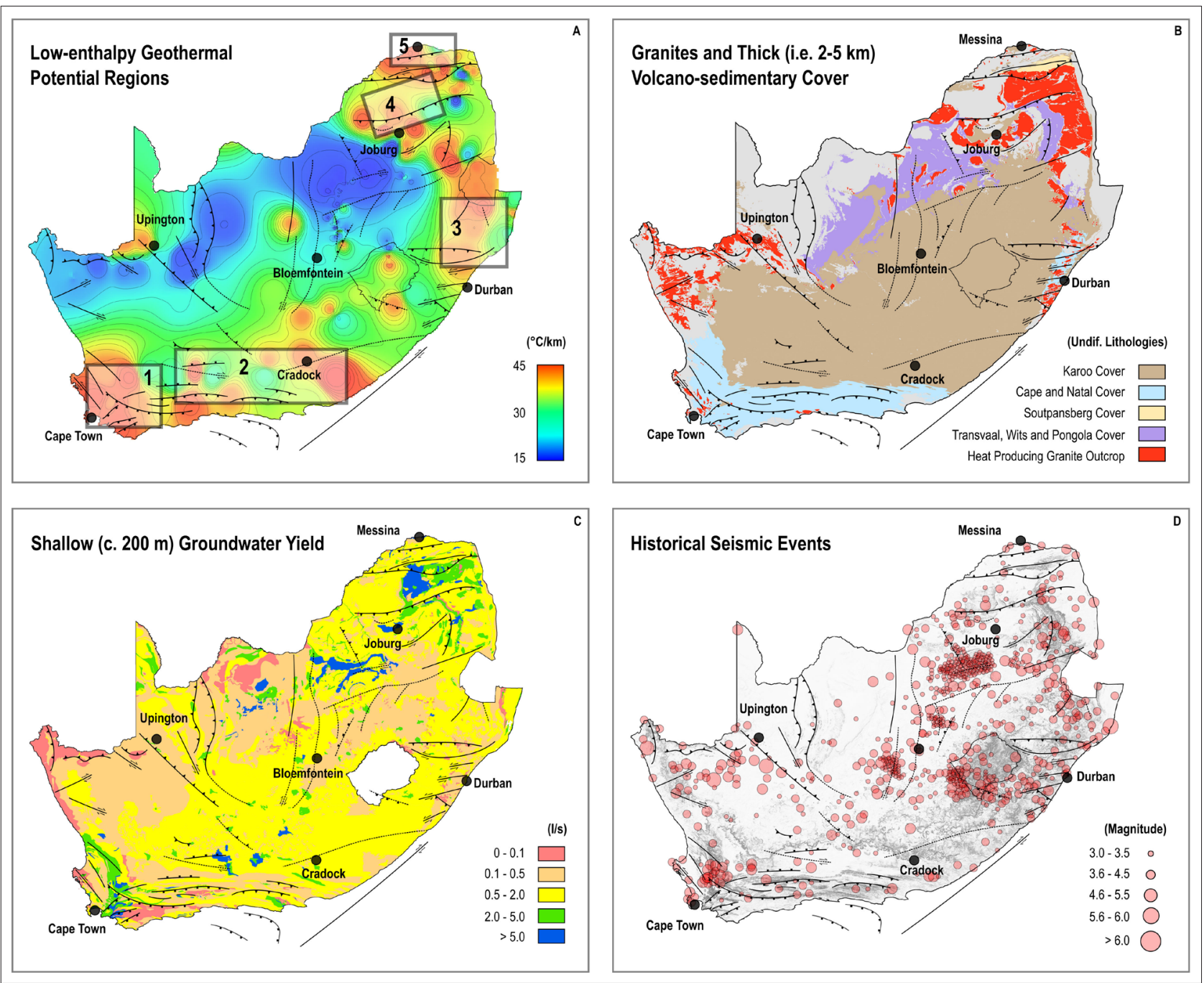

Figure 4: (a) Potentially viable low-enthalpy geothermal investigation regions (1-5); based on (b) high heat producing plutonic rocks and overlying volcanosedimentary rocks; and (c) approximate groundwater yield (data from the South African Department of Water Affairs). (d) Regional seismicity (data from the Council for Geoscience).

Importantly, the cost of initial exploration and development of lowenthalpy geothermal energy is high ${ }^{3}$ and development in Germany was largely enabled by a Governmental Renewable Energy Feed-In Tariff of $15 \mathrm{EURc} / \mathrm{kWh}^{60}$. The impact of financial incentives in South Africa is also noticeable with the Renewable Energy Independent Power Producer Procurement Programme, which has resulted in the cost of wind and solar being reduced by $46 \%$ and $71 \%$, respectively. ${ }^{1}$ Including geothermal in this programme could potentially accelerate further research and development and may result in geothermal being added to South Africa's future energy mix.

\section{Conclusions and recommendations}

The results of this study suggest that despite geothermal (re)sources not being part of South Africa's renewable energy mix, the country does have some potential for harnessing low-enthalpy geothermal energy. We therefore recommend that South Africa seriously considers geothermal energy as another renewable option. However, there are several key factors that need to be addressed before harvesting of geothermal energy can occur.

South Africa still needs significant research and data acquisition, including: high-resolution ground-based geophysics, new and extensive downhole temperature measurements, structural mapping, and deep hydrogeological and isotope hydrochemical investigations. These data will allow for a more precise evaluation of South Africa's geothermal energy potential and also highlight any possible negative impacts, especially on groundwater quality and inducing seismicity. ${ }^{8}$ Finally, economic modelling is imperative to design mechanisms to adequately enable advanced geothermal research and development in South Africa.

\section{Acknowledgements}

We acknowledge the support provided by the Department of Science and Technology and Council for Geoscience (South Africa), and the Jena Structure and Tectonics Research Group (Germany). We appreciate the Reviewers' comments and suggestions that greatly improved this manuscript. This article is an Iphakade and AEON contribution, numbers 166 and 168, respectively.

\section{Authors' contributions}

T.D. was the lead researcher and primary author; M.D. provided supervision and reviewed the manuscript; C.M., T.N., L.C. and D.C. reviewed the final manuscript.

\section{References}

1. South African Department of Energy. Annual report 2015/16. Pretoria: Department of Energy; 2016. Available from: http://www.energy.gov.za/files/ Annual\%20Reports/DoE-Annual-Report-2015-16.pdf 
2. Huenges E, Ledru P. Geothermal energy systems: Exploration, development, and utilization. Hoboken, NJ: John Wiley \& Sons; 2011. http://dx.doi. org/10.1002/9783527630479.

3. Dhansay T, De Wit M, Patt A. An evaluation for harnessing low-enthalpy geothermal energy in the Limpopo Province, South Africa. S Afr J Sci. 2014;110(3/4), Art. \#2013-0282, 10 pages. http://dx.doi.org/10.1590/ sajs.2014/20130282

4. Ntholi T. A technical and economic evaluation of a Passive Underground Mine-water Purification System (PUMPS): A geothermally powered geoengineering system designed for in-situ bio-remediation of acid mine water [PhD thesis]. Port Elizabeth: Nelson Mandela Metropolitan University; 2017.

5. Campbell SA, Mielke P, Götz AE. Geothermal energy from the Main Karoo Basin? New insights from borehole KWV-1 (Eastern Cape, South Africa). Geoth Energy. 2016;4(1), Art. \#9, 19 pages. http://dx.doi.org/10.1186/ s40517-016-0051-y.

6. Hooijkaas GR, Genter A, Dezayes C. Deep-seated geology of the granite intrusions at the Soultz EGS site based on data from $5 \mathrm{~km}$-deep boreholes. Geothermics. 2006;35(5):484-506. http://dx.doi.org/10.1016/j. geothermics.2006.03.003.

7. Sissingh W. Comparative tertiary stratigraphy of the Rhine Graben, Bresse Graben and Molasse Basin: Correlation of Alpine foreland events. Tectonophysics. 1998;300(1):249-284. http://dx.doi.org/10.1016/s00401951(98)00243-1.

8. Grünthal G. Induced seismicity related to geothermal projects versus natural tectonic earthquakes and other types of induced seismic events in Central Europe. Geothermics. 2014;52:22-35. http://dx.doi.org/10.1016/j. geothermics.2013.09.009

9. Freymark J, Sippel J, Scheck-Wenderoth M, Bär K, Stiller M, Fritsche JG, Kracht M. The deep thermal field of the Upper Rhine Graben. Tectonophysics. 2017;694:114-129. http://dx.doi.org/10.1016/j.tecto.2016.11.013.

10. Stober I, Bucher K. Hydraulic and hydrochemical properties of deep sedimentary reservoirs of the Upper Rhine Graben, Europe. Geofluids. 2015;15(3):464-482. http://dx.doi.org/10.1111/gfl.12122

11. Agemar T, Weber J, Schulz R. Deep geothermal energy production in Germany. Energies. 2014;7(7):4397-4416. http://dx.doi.org/10.3390/en7074397.

12. Stankiewicz J, De Wit M. 3.5 billion years of reshaped Moho, southern Africa. Tectonophysics. 2013;609:675-689. http://dx.doi.org/10.1016/j. tecto.2013.08.033

13. Schmitz MD, Bowring SA, De Wit MJ, Gartz V. Subduction and terrane collision stabilize the western Kaapvaal craton tectosphere 2.9 billion years ago. Earth Planet Sci Lett. 2004;222(2):363-376. http://dx.doi.org/10.1016/ s0012-821x(04)00220-1.

14. Krige LJ. Borehole temperatures in the Transvaal and Orange Free State. Proc Roy Soc Lond A. 1939;173(955):450-474. http://dx.doi.org/10.1098/ rspa.1939.0158.

15. Carte AE, Van Rooyen Al. Further measurements of heat flow in South Africa. Geol Soc S Afr. Special Publication. 1969;2:445-448.

16. Jones $M Q$. Heat flow in the Witwatersrand Basin and environs and its significance for the South African shield geotherm and lithosphere thickness. J Geophys Res-Sol Ea. 1988;93(B4):3243-3260. http://dx.doi.org/10.1029/ jb093ib04p03243.

17. Jones $M Q$. Heat flow and heat production in the Namaqua mobile belt, South Africa. J Geophys Res-Sol Ea. 1987;92(B7):6273-6289. http://dx.doi. org/10.1029/jb092ib07p06273.

18. Jones MQ. Heat flow anomaly in Lesotho: Implications for the southern boundary of the Kaapvaal craton. Geophys Res Lett. 1992;19(20):20312034. http://dx.doi.org/10.1029/92gl02207.

19. Thomas RJ. A tale of two tectonic terranes. S Afr J Geol. 1989;92(4):306321.

20. Linol B, De Wit MJ. Origin and evolution of the Cape Mountains and Karoo Basin. Regional Geology Reviews series. Cham, Switzerland: Springer International Publishing; 2016. http://dx.doi.org/10.1007/978-3-319-40859-0.

21. Viljoen J, Siegfried H. Kuils River Batholith. In: Johnson M, editors. Pretoria: Catalogue of South African Lithostratigraphic Units; 2009. p. 13.
22. Voordouw RJ, Rajesh HM. Granitoids from the Margate Terrane and their implications for tectono-magmatic models of the Natal Metamorphic Province (South Africa). S Afr J Geol. 2012;115(1):47-64. http://dx.doi.org/10.2113/ gssajg.115.1.47.

23. Andreoli MA, Hart RJ, Ashwal LD, Coetzee H. Correlations between U, Th content and metamorphic grade in the western Namaqualand Belt, South Africa, with implications for radioactive heating of the crust. J Petrol. 2006;47(6):1095-1118. http://dx.doi.org/10.1093/petrology/egl004.

24. Meyer M, Robb LJ, Anhaeusser CR. Uranium and thorium contents of Archaean granitoids from the Barberton Mountain Land, South Africa. Precambrian Res. 1986;33(4):303-321. http://dx.doi.org/10.1016/03019268(86)90048-3.

25. Van Tonder DM, Mouri H. Petrology and geochemistry of the granitoid rocks of the Johannesburg Dome, central Kaapvaal Craton, South Africa. S Afr J Geol. 2010;113(3):257-286. http://dx.doi.org/10.2113/gssajg.113.3.257.

26. Good N, De Wit MJ. The Thabazimbi-Murchison Lineament of the Kaapvaal craton, South Africa: $2700 \mathrm{Ma}$ of episodic deformation. J Geol Soc London. 1997;154(1):93-97. http://dx.doi.org/10.1144/gsjgs.154.1.0093.

27. Walraven F, Kleeman GJ, Allsopp HL. Disturbance of trace-element and isotope systems and its bearing on mineralisation in acid rocks of the Bushveld Complex, South Africa. High heat production (HHP) granites, hydrothermal circulation and ore genesis. London: Institute of Mining and Metallurgy; 1985. p. 393-408.

28. Kenan AO, Chirenje E. Uranium in South Africa: Exploration and supply capacity. Nat Res Conserv. 2016;4(2):25-33. http://www.hrpub.org/journals/ article_info.php?aid=5013.

29. Robb LJ, Davis DW, Kamo SL, Meyer FM. Ages of altered granites adjoining the Witwatersrand Basin with implications for the origin of gold and uranium. Nature. 1992;357(6380):677-680. http://dx.doi.org/10.1038/357677a0.

30. Dhansay T, Brandl G, De Wit MJ. Fractal geometry of the fault network across the Soutpansberg Mountains, Limpopo, South Africa. S Afr J Geol. 2016;119(1):235-242. http://dx.doi.org/10.2113/gssajg.119.1.235.

31. Brandt MB, Saunders I. New regional moment tensors in South Africa. Seismol Res Lett. 2011;82(1):69-80. http://dx.doi.org/10.1785/gssrl.82.1.69.

32. Viola G, Kounov A, Andreoli MA, Mattila J. Brittle tectonic evolution along the western margin of South Africa: More than 500Myr of continued reactivation. Tectonophysics. 2012;514:93-114. http://dx.doi.org/10.1016/j. tecto.2011.10.009.

33. Nemangwele F. Radon in the Cango Caves [MSc thesis]. Cape Town: University of the Western Cape; 2005. http://etd.uwc.ac.za/xmlui/handle/11394/231.

34. Goedhart ML, Booth PW. A palaeoseismic trench investigation of early Holocene neotectonic faulting along the Kango Fault, southern Cape Fold Belt, South Africa - Part I: Stratigraphic and structural features. S Afr J Geol. 2016;119(3):545-568. http://dx.doi.org/10.2113/gssajg.119.3.545.

35. Dingle RV, Scrutton RA. Continental breakup and the development of post-Paleozoic sedimentary basins around southern Africa. Geol Soc Am Bull. 1974;85(9):1467-1474. http://doi.org/10.1130/00167606(1974)85<1467:cbatdo>2.0.c0;2.

36. Boshoff R, Reenen DV, Smit CA, Perchuk LL, Kramers JD, Armstrong R. Geologic history of the Central Zone of the Limpopo Complex: The West Alldays area. J Geol. 2006;114(6):699-716. http://dx.doi.org/10.1086/507615.

37. Eglington BM. Evolution of the Namaqua-Natal Belt, southern Africa A geochronological and isotope geochemical review. J Afr Earth Sci. 2006;46(1):93-111. http://dx.doi.org/10.1016/j.jafrearsci.2006.01.014.

38. Voordouw RJ. A D3 shear zone in the Margate Terrane and its implications for regional deformation in the Natal Metamorphic Province (South Africa). S Afr J Geol. 2010;113(2):183-194. http://dx.doi.org/10.2113/gssajg.113.2.183.

39. Baiyegunhi C, Mupandawana NW, Oloniniyi TL, Gwavava O. Characterization of Aliwal North Hotspring in the Eastern Cape Province of South Africa, using magnetic, electromagnetic and radiometric methods. IOSR J Eng. 2014;4(12):43-58. http://dx.doi.org/10.9790/3021-041203043058.

40. Nyabeze PK, Gwavava 0. Investigating heat and magnetic source depths in the Soutpansberg Basin, South Africa: Exploring the Soutpansberg Basin Geothermal Field. Geoth Energy. 2016;4(1):1-20. http://dx.doi.org/10.1186/ s40517-016-0050-z. 
41. Verhagen B, Butler M, Levin M, Van Wyk E. Environmental isotopes assist in groundwater sustainability assessment of the Taaibosch fault zone, Northern Province, South Africa. In: Sililo 0, editor. Groundwater: Past achievements and future challenges. Rotterdam: Balkema; 2000. p. 673-678.

42. Clauser $\mathrm{C}$, Huenges $\mathrm{E}$. Thermal conductivity of rocks and minerals. In: Ahrens T, editor. Rock physics \& phase relations: A handbook of physical constants. Washington DC: American Geophysical Union; 1995. p. 105-126. http:// dx.doi.org/10.1029/rf003.

43. Ellis AJ. Chemical geothermometry in geothermal systems. Chem Geol. 1979;25(3):219-226. http://dx.doi.org/10.1016/0009-2541(79)90143-8.

44. Bullard EC. Heat flow in South Africa. R Soc Lond Proc Ser A Math Phys Eng Sci. 1939:474-502.

45. Kent LE. The thermal waters of the Union of South Africa and South West Africa. S Afr J Geol. 1949;52(1):231-264.

46. Carte AE. Heat flow in the Transvaal and Orange Free State. P Phys Soc Lond B. 1954;67(9):664. http://dx.doi.org/10.1088/0370-1301/67/9/302

47. Bouwer R. Borehole temperatures in the Klerksdorp and Orange Free State areas. Bulletin 22. Pretoria: Geological Survey of the Union of South Africa Department of Mines; 1954. p. 35.

48. Gough DI. Heat flow in the southern Karroo. Proc Roy Soc Lond A. 1963;272(1349):207-230. http://dx.doi.org/10.1098/rspa.1963.0050.

49. Hoole J. The development of Lilani hot springs: An analysis of socioeconomic and environmental impacts [MSc thesis]. Pietermaritzburg: University of Natal; 2000. p. 165. http://researchspace.ukzn.ac.za/xmlui/ handle/10413/3799.

50. Woodford A, Chevallier L. Hydrogeology of the Main Karoo Basin: Current knowledge and future research needs. WRC report no. TT179/02. Pretoria: Water Research Commission; 2002. p. 482.

51. Merkel B, Steinbruch F. Preliminary hydrogeological investigation on the Nhambita hot spring, Mozambique. Report to the Department of Scientific Services, Gorongosa National Park. 2007. p. 33. Available from: http:// www.gorongosa.org/our-story/science/reports/preliminary-hydrogeologicalinvestigation-nhambita-hot-spring-mozambique.
52. Grootjans AP, Grundling PL, Grundling A, Linström A, Engelbrecht J, Price JS. Spring mires fed by hot artesian water in Kruger National Park, South Africa. Mires and peat. 2010;6(7):1-10. http://pixelrauschen.de/wbmp/media/ map06/map_06_07.pdf.

53. Viljoen J, Stapelberg F, Cloete M. Technical report on the geological storage of carbon dioxide in South Africa. Pretoria: Council for Geoscience; 2010. p. 236.

54. Olivier J, Venter JS, Jonker CZ. Thermal and chemical characteristics of hot water springs in the northern part of the Limpopo Province, South Africa. Water SA. 2011;37(4):427-436. http://dx.doi.org/10.4314/wsa.v37i4.1.

55. Boekstein M. Revitalising the healing tradition - health tourism potential of thermal springs in the Western Cape [Doctor of Technology thesis]. Cape Town: Cape Peninsula University of Technology; 2012. p. 182. http:// digitalknowledge.cput.ac.za/xmlui/handle/11189/1313.

56. Olivier J, Jonker CZ. Optimal utilisation of thermal springs in South Africa WRC report no. TT577. Pretoria: Water Research Commission; 2013. p. 13.

57. Robins N. The thermal springs of Swaziland: A review. In: Groundwater: A New Paradigm. Proceedings of the Geological Society of South Africa Biennial Conference; 2013 September 17-19; Durban, South Africa. Johannesburg: Geological Society of South Africa; 2013. p. 7. http://nora. nerc.ac.uk/503375/.

58. Hicks N, Davids S, Beck B, Green A. Investigation of $\mathrm{CO}_{2}$ storage potentia of the Durban Basin in South Africa. Energy Procedia. 2014;63:5200-5210. http://dx.doi.org/10.1016/j.egypro.2014.11.551.

59. De Kock M, Beukes N, Götz A, Cole D, Robey K, Birch A, et al. Open file progress report on exploration of the Southern Karoo Basin through CIMERAKARIN borehole KZF-1 in the Tankwa Karoo, Witzenberg (Ceres) district. Johannesburg: University of Johannesburg; 2015. p. 12.

60. Bakhtyar B, Fudholi A, Hassan K, Azam M, Lim CH, Chan NW, et al. Review of $\mathrm{CO}_{2}$ price in Europe using feed-in tariff rates. Renew Sust Energ Rev. 2017;69:685-691. http://dx.doi.org/10.1016/j.rser.2016.11.146. 